\title{
VIRAR OUTRO: A AUTORIA EM A QUEDA DO CÉU
}

\section{BECOMING OTHER: AUTHORSHIP IN THE FALLING SKY}

\author{
Marcus A. S. Wittmann (PPGAS/Museu Nacional/UFRJ) \\ wittmann.marcus@gmail.com \\ Eduardo Santos Schaan (UFRGS) \\ eduardo.schaan@gmail.com
}

\begin{abstract}
RESUMO: Este trabalho analisa a construção da autoria na obra A queda do céu: palavras de um xamã yanomami, de Davi Kopenawa e Bruce Albert, na perspectiva das múltiplas agências, atores e vozes configuradoras do discurso, o qual varia entre autobiografia, discurso político, tratado cosmopolítico e crítica xamânica. Em um primeiro momento, o artigo discute brevemente a noção de autoria na tradição ocidental, marcada pela individualidade e pela propriedade; em seguida, demonstra como essa concepção é elidida em A queda do céu, que vincula a autoria à noção de "virar outro", a partir do entrelaçamento de múltiplas vozes e imagens espirituais, resultando em uma polifonia da floresta.
\end{abstract}

PALAVRAS-CHAVE: A queda do céu; autoria; alteridade; polifonia.

ABSTRACT: This paper analyzes the construction of authorship in the book The Falling Sky: Words of a Yanomami Shaman, by Davi Kopenawa and Bruce Albert, from the perspective of the multiple agencies, actors and voices that configure the discourse, which varies between autobiography, political discourse, cosmopolitical treatise and shamanic criticism. First, the article briefly discusses the notion of authorship in the Western tradition, marked by individuality and property; then, it demonstrates how this conception is elided in The Falling Sky, which links authorship to the notion of "becoming other", from the interweaving of multiple voices and spiritual images, resulting in a polyphony of the forest.

KEY-WORDS: The Falling Sky; authorship; alterity; polyphony.

Da equação eu parte do Cosmos, ao axioma Cosmos parte do eu (Oswald de Andrade, Manifesto Antropófago) 


\section{Introdução}

Depois de transcorridas centenas de páginas de 24 capítulos divididos em três partes de um discurso que parece variar entre autobiografia, discurso xamânico yanomami e uma crítica ao "povo das mercadorias", o leitor de A queda do céu: palavras de um xamã yanomami - livro lançado primeiramente em 2010, em francês, por Davi Kopenawa, xamã yanomami, e Bruce Albert, antropólogo francês, e cinco anos após em língua portuguesa aterrissa em um postscriptum de autoria de Albert. Intitulado "Quando o eu é outro (e viceversa)", Albert faz uma análise e conta como o livro surgiu, afirmando que A queda do céu é um "texto escrito/falado a dois" (KOPENAWA; ALBERT, 2015, p. 537). Entretanto há muito mais que duas figuras, dois personagens, e poderíamos dizer, mais que dois autores no livro. Como veremos, tanto Albert e Kopenawa, quanto as vozes, agentes e atores trazidos à tona nas páginas, palavras e discursos que integram o livro, são múltiplos, plurais e agenciam diferentes corpos, epistemologias e ontologias.

Em um primeiro momento, esse texto irá discutir brevemente a noção de autoria no Ocidente em relação a suas mudanças epistemológicas históricas, convergindo ao chamado "retorno do autor" (KLINGER, 2007; FOSTER, 2014). A seguir, será discutida a própria obra de Kopenawa e Albert, focando a análise na ideia de "virar outro" e em como isso elide a noção de autoria corrente, tornando-a mais complexa a partir de um conjunto de transformações dos autores envolvidos. Nessas transformações, entrelaçam-se a força de diversas vozes das imagens espirituais xapiri, bem como de Kopenawa e seus parentes, do povo Yanomami e seu demiurgo Omama, de Albert e dos brancos e suas mercadorias. A partir do encontro, como uma força catalisadora de mudanças, e da noção largamente utilizada na narrativa de "virar outro", podemos ver como a autoria é modulada por uma polifonia de vozes da floresta.

\section{Individualidade e propriedade na autoria ocidental}

A queda do céu, ao mesmo tempo que se constitui como um discurso e crítica xamânica indígena, é também construído e divulgado enquanto um livro, um produto que é uma mercadoria ocidental inserida em uma economia editorial. Entretanto, dessa dicotomia surgem características únicas nessa obra. Desse modo, iniciamos nossa reflexão trazendo 
subsídios acerca da construção da figura do autor na literatura ocidental. Segundo Foucault (2001), a noção de autoria surge ao longo do século XVIII e no início do século XIX, associada à ideia de transgressão. O autor, enquanto figura, ganha relevância e contornos a partir do momento em que os discursos se tornam transgressores, sendo apropriados penalmente e incluídos em regimes de propriedade. O discurso, anteriormente à ideia de autoria, "foi historicamente um gesto carregado de riscos antes de ser um bem extraído de um circuito de propriedades" (FOUCAULT, 2001, p. 275). No decorrer dos séculos XVII e XIX, os discursos passam gradativamente a serem incorporados em regimes de propriedade e possibilidade e, por isso mesmo, serem punidos. Dessa forma, os autores obtêm, de um lado, os direitos de propriedade sobre suas obras, mas tornam-se regidos por uma série de leis e regulamentações de seus escritos, impedindo-os de se tornarem transgressores de discursos hegemônicos.

Foucault (2001) também ressalta como a noção de autoria, antes desse período, era pouco posta em questão, sendo outros critérios - como a antiguidade de um texto ou referências gerais a antigos filósofos - motivos suficientes para atestar a autoria e a veracidade de um texto. Calavia Sáez (2013), de forma similar, associa o fortalecimento da ideia de autoria ao controle imposto por autoridades, mas remete esse processo ao século XVII, mencionando os livros espanhóis publicados na época. Nesses, junto ao nome do autor, vinha a homenagem a algum aristocrata, o privilégio real que permitia a publicação da obra e a autorização da censura, garantindo que o texto não ofendia a Fé e a Moral. Em ambos os casos, a autoria de um texto é um processo associado a um regime de poder (a propriedade privada, o poder real), como também à submissão de autores ao exercício de controle por esses poderes.

Analogamente, o surgimento da autoria coincide com a individualização do ser humano segundo a perspectiva ocidental. Foucault (2001, p. 267), nesse sentido, afirma que “essa noção do autor constitui o momento crucial da individualização na história das ideias, dos conhecimentos, das literaturas, e também na história da filosofia, e das ciências". Em um processo que se inicia ao fim da Idade Média, fatores diversos como o empirismo inglês, o racionalismo e a fé na Reforma fazem com que o indivíduo ganhe cada vez mais prestígio, o que se reflete no aumento da importância pessoal do autor (BARTHES, 2004). Esses dois processos, tanto de individualização da autoria quanto sua relação cada vez mais íntima com as normas de propriedade, foram bastante estudados pela literatura referente à área, mas serão importantes ao refletir sobre a obra de Kopenawa e Albert, em que as noções de 
individualidade serão postas em questão face à multiplicidade de autorias presentes no discurso xamânico.

É conhecida a ideia, elaborada ao fim dos anos 60 por Foucault (2001) e Barthes (2004), de que estaria ocorrendo a morte do autor. Esse conceito partia de uma associação entre a escrita e a morte, em que, se nas antigas epopeias gregas as narrativas serviam para perpetuar a memória do autor, no Ocidente moderno as narrativas serviam para obliterar a figura do autor, passando a valer apenas o texto escrito. Ou seja, a individualidade do autor se tornava cada vez menos relevante, suas características particulares desapareciam e se reforçava a importância da linguagem, que passava a assassinar seu autor (FOUCAULT, 2001, p. 269). Dessa forma, aspectos formais da obra, como o próprio texto e suas relações internas, assumiam proeminência, relegando ao autor o papel de uma função (FOUCAULT, 2001), cuja importância derivava não de sua figura individual, mas da facilidade desse rótulo para organizar, categorizar e analisar um conjunto de textos. Klinger (2007), ao traçar uma retrospectiva desse fenômeno teórico, que ganhou força ao longo das décadas de 60 e 70, sugere que a desaparição que então ocorria não era do autor, mas sim de um de seus tipos: o autor romântico e humanista do século XIX e XX. A partir do questionamento do sujeito moderno e de sua subjetividade, a ideia de verdade e unicidade que se ligava à autoria se desfaz.

Ao fim do século XX, no entanto, acontece o movimento chamado por Klinger (2007) de "retorno do autor". Nele, as diferentes vozes políticas e artísticas retomam o uso da primeira pessoa, questionando mecanismos que geram efeitos de neutralidade e transparência da escrita. O retorno do autor aparece ao mesmo tempo em que a arte contemporânea se pergunta como representar a alteridade (FOSTER, 2014), em um processo em que o Outro (como diferença cultural) se torna um foco do processo artístico, e não mais categorias anteriores que desconsideravam diferenças culturais. Nesse retorno, o autor ressurge a partir de sua subjetividade, mas sem a autoridade, característica da autoria que o associava à verdade e forçava um pacto narrativo típico do autor romântico e humanista, em que o leitor assumia um papel passivo de recepção. Assim, a escrita e suas formas de representação são repensadas, centrando-se na relação entre sujeitos e experiência, em que o artista se percebe como um sujeito incompleto, sem essencialismo e suscetível à autocriação (KLINGER, 2007, p. 45). Foster (2014, p. 33) ainda afirma que o retorno do autor é a continuidade de sua crítica, uma forma de manter o questionamento sobre a identidade do artista, o que, segundo Klinger (2007), frequentemente leva o artista a se perceber como outro. 
A reflexão feita acima, longe de procurar ser um estudo aprofundado sobre o conceito de autoria e a história de sua ideia nas últimas décadas, nos permite, não obstante, criar um fundo para refletir sobre $A$ queda do céu. Essa trajetória histórica da autoria no Ocidente reforça um processo de desconstrução e questionamento de identidades e culturas essencialistas que culmina no atual retorno do autor. Ainda assim, não é por acaso que esse processo também promove a importância do sujeito criador novamente - Klinger (2007) escreve que o retorno do autor está ligado também, além das alterações nas possibilidades de representar e criar artisticamente, ao próprio momento do capitalismo ao fim do século XX e início do século XXI, tendo como consequência a relevância midiática da figura do indivíduo. Nesse processo, por um lado, o discurso artístico procura a alteridade e usa-a como forma de criar esteticamente, mas corre o risco de tornar essa produção uma forma de individualismo usado em termos midiáticos. É perceptível, portanto, que a relação entre propriedade e individualidade (mesmo quando questionadas) marca o centro do debate sobre autoria e, de certa forma, sobre a própria arte nos espaços ocidentais. Ao descrever e analisar, a seguir, a obra de Kopenawa e Albert, entretanto, esses conceitos se tornam cada vez mais ambivalentes, visto que a ideia de "virar outro" a partir do encontro é levada, pela própria narrativa, pelo contexto de produção da obra e pelo contexto ameríndio da qual faz parte, a seus limites.

\section{A queda do céu: o mundo de Omama}

A queda do се́u é, antes de mais nada, um discurso direcionado ao Outro e, mais especificamente, a um outro que não quer ouvir: o branco, ou, nas palavras de Davi Kopenawa, "o povo da mercadoria". O povo Yanomami, que mora entre a fronteira da Venezuela e do Brasil, teve contato com os não indígenas no início do século XX, mas essa relação se intensificou sobretudo a partir da década de 40. A obra foi considerada por Albert uma heterobiografia (KOPENAWA; ALBERT, 2015, p. 540), ou seja, uma biografia do outro, em que o antropólogo francês redige e organiza centenas de horas de gravações de falas de Kopenawa. A queda do céu"centra-se na história desse xamã yanomami, sua infância, suas primeiras experiências com os brancos e com os seres espirituais xapiri. Mostra ainda seu amadurecimento e suas reflexões sobre política e xamanismo na floresta, tendo como foco 
principal o questionamento das ações dos brancos em sua vontade de produzir mercadorias e destruir sua floresta natal.

Na obra, Davi Kopenawa narra os primeiros contatos que sua própria aldeia e as aldeias próximas sofreram com os não indígenas e que geraram diversas epidemias em sequência (chamadas de epidemias xawara, causadas por espíritos maléficos ligados ao minério e a mercadorias), causando a morte de muitos de seus parentes. Essas incursões eram motivadas pela vontade do governo brasileiro de, primeiramente, delimitar suas fronteiras com a Venezuela e, a seguir, instalar postos do Serviço de Proteção aos Índios (SPI) para agrupar a população Yanomami, tendo em vista os projetos de desenvolvimento, feitos principalmente pela Ditadura Militar (1964-1985), para instalar estradas e polos de extração de minérios na terra yanomami. Dessa forma, A queda do céu parte da visão de Kopenawa sobre esse processo, que acontece juntamente à sua iniciação xamânica. Ambos os fatos se correlacionam à invasão de milhares de garimpeiros durante a década de 70 e 80 a suas terras em busca de ouro, sob o questionamento de Davi Kopenawa entre indígenas e em fóruns internacionais para proteger a Floresta Amazônica.

O processo de criação do livro inicia-se em 1989, quando Kopenawa estava em Brasília, na casa de Alcida Ramos, antropóloga brasileira, vendo pela televisão as imagens de destruição de sua floresta por garimpeiros. Naquele contexto, afirma simplesmente: "Os brancos não sabem sonhar, é por isso que destroem a floresta desse jeito" (KOPENAWA; ALBERT, 2015, p. 531). A partir dessa afirmação, Ramos estimula Kopenawa a desenvolver suas ideias, gravando-as e posteriormente as entregando a Albert, um antropólogo francês que há anos já trabalhava com Davi Kopenawa e com o povo Yanomami. Albert narra que seus primeiros contatos com aquele povo em 1975 eram marcados por uma dificuldade inicial, tanto linguística quanto corporal, o que, no postscriptum do livro, leva-o a afirmar que o trabalho de antropologia requer "atingir os limites do próprio pensamento para começar a descobrir o dos outros" (KOPENAWA; ALBERT, 2015, p. 519). Em 1975, Albert narra suas primeiras impressões do povo Yanomami, em que se choca com o "barroquismo turbulento" (KOPENAWA; ALBERT, 2015, p. 517) do encontro entre projetos de desenvolvimento para a construção da Perimetral Norte e a realidade indígena, em que grupos yanomami que perambulavam "meio vestidos com camisetas publicitárias ou de campanhas eleitorais, sujas e rasgadas [...] esgueiravam-se no barulho ensurdecedor de caminhões e escavadeiras, para pedir aos operários, com sorrisos imperturbáveis, comida, roupas, latas e sacos plásticos usados" (KOPENAWA; ALBERT, 2015, p. 517). As imagens, sentimentos e situações 
aludidas nessa passagem se chocam com as descrições de Kopenawa sobre os xapiri. Como veremos, as impressões desse primeiro contato com os Yanomami escondiam um mundo xamânico povoado por seres coloridos com pinturas corporais, seus adornos plumários, caminhos espelhados e poderosos cantos.

Após a já citada primeira gravação fornecida por Kopenawa, em 1989, Albert o visita em sua aldeia e lá Davi Kopenawa lhe comunica sua vontade de expor da melhor maneira possível sua visão sobre as ações dos não indígenas. Ele propõe ao francês que transcreva, traduza e organize uma série de gravações que Kopenawa produz até 1993, algumas das quais lançadas à parte em pequenos textos (KOPENAWA; ALBERT, 1999; ALBERT, 2002). No entanto, os dois autores decidem criar um trabalho de maior fôlego, apesar da dificuldade, que transcorre entre 1993 e 2001, produzindo milhares de páginas de material transcrito do Yanomami. O objetivo de Kopenawa era fazer ouvir suas palavras e fazer com que os brancos entendessem de onde essas palavras vêm e como são diferentes daquelas proferidas pelos não indígenas, como nesse trecho em que se dirige ao antropólogo:

Os brancos não pensam muito adiante no futuro. Sempre estão preocupados demais com as coisas do momento. É por isso que eu gostaria que eles ouvissem minhas palavras através dos desenhos que você fez delas; para que penetrem em suas mentes. Gostaria que, após tê-las compreendido, dissessem a si mesmos: "Os Yanomami são gente diferentes de nós, e no entanto suas palavras são retas e claras. Agora entendemos o que eles pensam. [...] Não têm peles de imagens, mas conhecem os espíritos xapiri e seus cantos. Querem defender sua terra porque desejam continuar vivendo nela como antigamente" (KOPENAWA; ALBERT, 2015, p. 65).

Assim, o livro narra a história do próprio Davi Kopenawa, bem como os "fundamentos poético-metafísicos" (VIVEIROS DE CASTRO, 2015, p. 27) da visão yanomami do mundo. A obra estrutura-se em três partes: "Devir outro", "A fumaça do metal" e "A qqueda do céu", além de um prólogo, escrito por ambos os autores, e um postscriptum, feito por Albert. Podese dizer, de forma bastante esquemática, que na primeira parte, "Devir outro", narram-se a infância de Davi Kopenawa, o universo dos espíritos e a origem do mundo através de Omama, o demiurgo. Em “A fumaça do metal”, está presente a visão xamânica sobre os primeiros contatos, sobre a busca por metais e sua relação direta com as epidemias; enquanto que em "A queda do céu" conta-se sobre a visão yanomami sobre os brancos, o espírito da floresta e o risco de o céu cair, ou seja, acontecer a destruição da Terra causada pelo fim das florestas e de suas bases assentadas em fundações metálicas. Esta Terra aludida aqui pode ser entendida como o planeta em que vivemos; para os Yanomami, o conceito que abarca essa 
totalidade, mas também uma multiplicidade de terras e estratos cosmológicos, é Hutukara. Essa Terra-Floresta é o estrato geológico no qual vivemos, com suas florestas e rios, sendo formada pelo último céu que desabou, e agora essa floresta tem sido ameaçada pela queda do novo céu que a cobre. A perpetuação do mundo, no pensamento yanomami, se deve, por sua vez, à permanência da floresta e à comunicação com os xapiri que os xamãs estabelecem. Nessas diferentes seções, vários personagens indígenas e não indígenas se cruzam, visões de mundo yanomami se chocam com aquelas dos brancos, e episódios da vida de Davi Kopenawa se emaranham com a história do contato dos Yanomami com a sociedade nacional.

Ao longo do livro, as palavras de Kopenawa centram-se no mundo criado por Omama e o conhecimento vindo através de espíritos, os xapiri. Esses são seres-imagem, que são o coração (a imagem interior) de animais, plantas, pedras, objetos, astros, floresta, entre tantos outros seres, e que vêm aos xamãs, que são capazes de os perceber. Os xapiri são "como fotografias" (KOPENAWA; ALBERT, 2015, p. 116) dos animais, além de serem inúmeros: "São como eu, de pé diante dos espelhos do hotel. Parecem únicos, mas suas imagens se justapõem ao longe sem fim" (KOPENAWA; ALBERT, 2015, p. 116). Foram criados por Omama para proteger e curar os seres humanos, sendo o filho do próprio demiurgo o primeiro xamã existente. Os xapiri são "Outros", sendo imagens dos ancestrais yarori que se transformaram no primeiro tempo, quando os animais eram humanos e se metamorfoseavam continuamente. Aquele tempo acabou quando o primeiro céu desabou, soterrando os animais e dele restando os espíritos xapiri, que são o interior desses primeiros seres. Em relação à sua aparência, os xapiri se parecem com humanos, sendo minúsculos e luminosos, invisíveis para as pessoas comuns. Eles dançam e cantam para os xamãs, que os fazem descer do céu por caminhos espelhados e brilhantes, para quem apresentam suas danças e cantos. Esses cantos são a forma de comunicação entre o xamã e os xapiri e, através desses, o xamã pode conhecer o passado e o presente, o mundo dos brancos, o que acontece na floresta ou saber como curar pessoas doentes. Os xapiri se alojam em casas de espíritos no peito do céu, mas suas imagens existem também no peito dos xamãs, como Kopenawa. Conhecê-los e fazê-los dançar é fruto de um grande trabalho de iniciação, propiciado pelo pó de yakoana, preparado com a casca de uma árvore amazônica, que permite ver essas imagens.

No caso de Kopenawa, seu sogro e seu padrasto, que eram também xamãs, sopravam pó de yakoana em seu nariz, passando-lhes alguns de seus próprios xapiri e permitindo que ele próprio se tornasse, por sua vez, um xamã. Deste modo, não só Davi Kopenawa constrói 
uma posição de xamã, mas tem seu próprio corpo construído como tal, seja pelos xapiri que o reconstroem, trocando partes como garganta e boca de lugar para poder receber seus cantos e ser possível de os transmitir, mas também pelo seu sogro e padrasto, que o alimentavam com o pó de yakoana. Ao longo de décadas, Kopenawa se esforçou em trazer cada vez mais xapiri de diversos tipos para sua casa, como do espírito gavião, dos tatus-canastra, dos próprios espíritos napepe (dos ancestrais dos não indígenas), o que lhe permite curar doentes e proteger a floresta. Quando o xamã recebe o pó de yakoana, seus olhos morrem e se tornam fantasma: ele se torna outro e pode entrar no mundo dos xapiri.

Neste ponto, poderíamos retomar a reflexão levantada por Foucault (2001), que já foi mencionada anteriormente. Se o autor francês citava a morte do autor, nesse caso, também percebemos que Kopenawa "morre" e se torna fantasma para poder entrar em contato com os xapiri e as alteridades da cosmologia yanomami em geral, o que possibilita a apreensão de seus conhecimentos como xamã e, em última instância, a própria criação dessa narrativa. Nesse sentido, a partir da teoria do filósofo francês e da experiência de Kopenawa, ambos os autores morrem. Os resultados, porém, são muito diversos: na primeira teoria, a morte do autor é consequência da perda da relevância de características individuais em um processo de proeminência da escrita e da valorização da exegese dos leitores e, se seguirmos Klinger (2007), isso transcorria em um cenário de desaparecimento do autor romântico e humanista do século XIX. Já na morte do xamã yanomami, não há um apagamento ou um desaparecimento. Em consonância a outras etnografias de sociedades ameríndias, como Cesarino (2008), estudando os Marubo, o papel do xamã e de sua linguagem é justamente traduzir diferentes singularidades e agências. É por Kopenawa "morrer" e conseguir transitar entre mundos (como o mundo dos vivos e dos espíritos) que se garante a relevância do xamã e dos conhecimentos presentes em A queda do céu. Assim, é a morte do autor que assegura, paradoxalmente, sua relevância na obra. Este processo será aprofundado a seguir, quando perceberemos a quantidade de "outros" que habitam o autor na obra em questão.

\section{O autor e seus outros}

A ideia de tornar-se outro é um dos elementos centrais da narrativa de Kopenawa, tanto em sentido positivo (uma transformação desejada), quanto em um sentido negativo, que traz medo e apreensão. Dessa forma, desde pequeno, Kopenawa já se tornava outro quando sonhava, sendo levado pelos xapiri a lugares da floresta, do céu ou de domínios subaquáticos. 
Além disso, ao falecerem por conta da epidemia, as pessoas Yanomami se tornavam outras, ou seja, viravam fantasmas. Os estrangeiros também têm uma linguagem outra, pois falam com língua de fantasmas em palavras indecifráveis. O processo de inalar a planta yakoana é, por si mesmo, virar outro, ser um xapiri. No início da narrativa, Kopenawa assume seu desejo de virar branco, quando vestia calças, óculos e camisa, tentando emular o modo como os brancos agem. As próprias florestas destruídas tornam-se outras. Em suma, o mundo narrado em A queda do céu é produto de inúmeras transformações em que as pessoas e seres podem tornar-se eles mesmos uma alteridade. Tornar-se outro é um fato frequente e comum pelo qual todos os elementos da narrativa passam, sendo que nenhum permanece com uma identidade constante, nem mesmo Omama, o demiurgo, que muito tempo atrás decidiu exilar-se no fim da Terra.

Todos esses devires e diferenciações acontecem a partir de encontros: o livro de Kopenawa é produto de um longo encontro entre Albert e o Yanomami, ocorrendo ao longo de quase 15 anos de gravações e conversas. A obra foi produzida a partir da aproximação do pensamento entre o antropólogo francês e o xamã yanomami, em que cada um tornou-se um pouco outro - sobre isso, Viveiros de Castro (2015, p. 27) no prólogo, argumenta que somente dois sujeitos "ex-centrados", em uma posição atípica e fronteiriça, poderiam ter produzido essa obra. Assim, a posição liminar dos sujeitos lhes permite compreender suas próprias culturas e visões de mundo de uma perspectiva também externa, o que possibilita uma análise mais incisiva e poderosa sobre cada povo. Bhabha (1998, p. 29), a propósito, já tratava da condição de unhomelissness, em que os sujeitos se realocam e se reposicionam no mundo a partir de um deslocamento - neste caso, Kopenawa, que vê seu mundo se alterar profundamente com a chegada da epidemia xawara a suas terras e, anos depois, passa a trabalhar como intérprete na Funai; Albert, por outro lado, como etnólogo cuja intenção é atingir o pensamento do outro, como já mencionado, e que passa por um longo processo de ressocialização pelo povo Yanomami.

A própria narrativa de $A$ queda do céu tem como eixo central o encontro entre indígenas e napepe (brancos/estrangeiros), quando as transformações radicais no mundo yanomami têm início, com grandes implicações àquele povo e à história do país até hoje. $\mathrm{O}$ encontro também é o que guia a relação entre Kopenawa e seus xapiri, que, desde criança, começam a dançar e cantar para eles em sonhos. Anos depois, é pelo contato entre ele, seu padrasto e seu sogro, ambos xamãs, que recebe seus primeiros espíritos-imagens e torna-se ele mesmo xamã. 
A ideia de tornar-se outro, que é um dos temas principais que percorrem a narrativa, foi estudada por teóricos como Luciani (2013) e Villaça (2000). Em um texto de Vilaça (2000) intitulado “O que significa tornar-se outro?”, ela mostra como o xamã da etnia Wari assume uma duplicidade corporal: ele é tanto um corpo humano, como também um corpo animal. Ambos adotam ora perspectivas humanas, ora perspectivas animais, gerando um jogo de espelhos, nas palavras da autora, que é replicado ao infinito - nota-se que é exatamente a mesma descrição que Kopenawa faz de seus xapiri, conforme citado anteriormente, que são espíritos múltiplos e incontáveis. Neste sentido, se conectarmos com a presente obra, percebemos essa mesma multiplicação das agências que criam a narrativa. Luciani (2013), complementarmente, salienta que um dos poderes de A queda do céu é justamente o fato de haver uma dialética entre as autorias de Kopenawa e Albert. Foi o processo de apreender sentidos alternativos que possibilitou manter a pluralidade e riqueza de imagens e ideias que se vê em A queda do céu: os autores não se transformaram completamente em indígena ou em branco, usufruindo de seu devir, isto é, de seu processo de tornar-se outro, para enriquecer a obra.

Ao lado do poder do encontro para o tornar-se outro, há a questão das múltiplas agências e autorias que ocupam cada autor. Albert já menciona esse tema em seu postscriptum, em que ele enumera diversos possíveis autores. Primeiramente, há os "eus" biográficos que se transformam ao longo do tempo de vida, com as modificações pelas quais passaram os dois autores principais no decorrer de 14 anos de trabalho conjunto. A seguir, há o duplo eu presente na narrativa: o livro é narrado em primeira pessoa, pela voz de Kopenawa, mas quem redige e cria esse efeito de primeira pessoa é o antropólogo. Ele afirma, a propósito, que somente uma grande identificação e contato com as palavras do xamã lhe permitiriam interpretar e traduzir da melhor forma possível as imagens de Kopenawa, sendo um texto de grande riqueza poética. Mas o eu da narrativa, além de ser Kopenawa, é também um alter ego de Albert, criando uma ambiguidade estrutural, em que ambos os autores se fazem presentes no mesmo pronome. A feitura do livro também é um produto conjunto, pois ele surge a partir de centenas de horas de gravações da voz do Yanomami, transcritas e traduzidas por Albert e posteriormente retrabalhadas pelos dois novamente, criando diversas camadas de textos que se acrescentam e autores que se modificam com o passar dos anos. Mesmo que a centralidade narrativa do livro sejam as palavras de Kopenawa, o texto possui centenas de notas de fim - inseridas exatamente no fim do livro para não concorrer com a 
narrativa de Kopenawa - escritas por Albert e possuindo grande valor etnográfico e histórico.

Os "eus" Davi Kopenawa e Bruce Albert que assinam o livro como autores são compostos por multiplicidades e ocupam lugares de trânsito, de devir, de não lugar. Albert é um antropólogo franco-marroquino que, incomodado com o contexto político intelectual do fazer antropológico na França, definiu seu lugar de atuação na América Latina, mais especificamente na Terra Indígena Yanomami, entre o Brasil e a Venezuela. Suas décadas de atuação, pesquisa e comprometimento político com esse povo indígena o colocam em uma posição entre epistemologias, a ocidental e a dos Yanomami. Já Kopenawa transita tanto por essas epistemologias, sendo também um estudioso dos não indígenas, quanto por ontologias diversas. Kopenawa é um xamã, um diplomata entre mundos — os dos humanos e dos não humanos - transitando entre estratos cósmicos, entre estados de consciência, tendo contato com entidades e lugares que só um xamã iniciado e experiente pode ter (VIVEIROS DE CASTRO, 2006; VIVEIROS DE CASTRO et al., 2008). Kopenawa transita entre xamã yanomami, sujeito autor, porta voz de seu povo, sujeito histórico e sujeito mítico (DANNER; DORRICO, 2017, p. 149).

Ademais, há outras autorias em cena além dos dois coautores principais: durante as gravações, Albert (KOPENAWA; ALBERT, 2015, p.539) informa que a presença do sogro, que era ele mesmo um importante xamã, complementando ou ironizando certos assuntos, era bastante comum, mas essa presença também é eclipsada através do "eu" do narrador. Isso aparece em uma passagem do livro, na qual o padrasto de Kopenawa assume o papel desse "eu", narrando sua experiência com os seres do mundo d'água e como aprendeu e tornou-se xamã (KOPENAWA; ALBERT, 2015, p. 105-109). O povo Yanomami também aparece como outro autor, segundo os próprios Albert e Kopenawa, através dos valores e histórias, como os vários mitos presentes, que perpassam o texto. Mesmo que essas histórias e mitos sejam coletivos, é Kopenawa quem — através da autoria do livro, seu sucesso e importância no contexto antropológico, político e ambientalista - transforma-se em um "porta-voz" do povo Yanomami, às vezes tendo sua imagem individual confundida com a coletividade e multiplicidade do seu povo.Fica claro, assim, que o pronome "eu" passa a abrigar uma série de diferentes autores da obra. Esses pronomes "eu" condensam uma multiplicidade de transformações e trajetórias dos sujeitos autores que não são somente transformações de uma identidade pessoal, mas sim a incorporação de diferenças e as transformações do "eu" ao longo da trajetória desses sujeitos e que se refletem no discurso e na obra como um todo. 
Cesarino (2008), estudando as artes verbais dos xamãs do povo Marubo, reflete que a pessoa Marubo, entre outros povos ameríndios, é caracterizada por sua fractalidade e por sua replicação de um mesmo esquema em escalas diferentes. Assim, o corpo do xamã é visto como ele mesmo sendo uma maloca (tal como Kopenawa o concebe), onde habitam seus duplos. Não haveria uma cisão entre corpo e alma (e mesmo essas categorias não traduzem adequadamente a percepção do xamã) e sim uma relação complementar de duplos e múltiplos. Cesarino (2008) inclusive descreve o xamã como uma pessoa múltipla, cujo trabalho é traduzir essas diferentes singularidades que habitam tanto seu interior, quanto o mundo a seu redor.

E por fim, há os xapiri. É bastante frequente que Kopenawa (esse "eu” do narrador) refira-se a suas palavras como sendo de origem dos próprios seres-imagem. Os xapiri poderiam ser entendidos como os autores não humanos de A queda do céu. Sua capacidade de falar em linguagem de fantasma - na língua dos napepe - é fruto do trabalho do espírito zangão Remori e do espírito Porepatari, um antigo espectro que sabe fazer trocas com não indígenas. Segundo o xamã:

Foram as imagens de Remori e Porepatari que colocaram em mim suas gargantas de espírito, para eu poder imitar a fala dos brancos. Ensinaram-me a pronunciar suas palavras uma após a outra com mais destreza e firmeza. Introduziram em mim a língua dos antepassados napenaperi. "Sozinho eu não teria conseguido e jamais seria capaz de fazer discursos nessa linguagem outra!" (KOPENAWA; ALBERT, 2015 , p. 384-385, grifos dos autores).

De forma similar, a capacidade de falar de forma clara e assertiva, ou seja, com a língua firme, é resultado da presença do espírito do gavião Kaokaoma. Essa imagem vai além de um simples ensinamento, de pequenas mudanças graduais: Kopenawa narra que todo o seu corpo foi reconstruído pelos xapiri (KOPENAWA; ALBERT, 2015, p. 118), isto é, a ideia de virar outro não é apenas uma metáfora, mas uma realidade na vivência do autor, em que suas capacidades corporais, discursivas e políticas foram refeitas pelo trabalho dos espíritos e outras entidades não humanas — uma imagem que inclusive ocorre em outras cosmologias indígenas (SANTOS-GRANERO, 2009). Além disso, o trabalho xamânico é, basicamente, uma forma de ser um microfone, conforme relata Kopenawa, transmitindo aos não iniciados as notícias do mundo espiritual. Através da narrativa, as palavras dos xapiri se fazem presentes pela voz de Kopenawa, o que é bem ilustrado nesse trecho:

Antigamente, não éramos obrigados a falar da floresta com raiva, pois não conhecíamos todos esses brancos comedores de terra e de árvores. Nossos 
pensamentos eram calmos. Escutávamos apenas nossas próprias palavras e os cantos dos xapiri. É o que queremos poder voltar a fazer. Não falo da floresta sem saber. Contemplei a imagem da fertilidade de suas árvores e a da gordura de seus animais de caça. Escuto a voz dos espíritos abelha que vivem em suas flores e a dos seres do vento que mandam para longe as fumaças de epidemia. Faço dançar os espíritos dos animais e dos peixes. Faço descer a imagem dos rios e da terra. Defendo a floresta porque a conheço, graças ao poder da yakoana. Seu espírito, Urihinari e o de Omama só são visíveis aos olhos dos xamãs. São suas palavras que dou a ouvir agora. Não são coisas que vêm só de meu pensamento. (KOPENAWA; ALBERT, 2015, p. 391, grifos nossos).

Dessa forma, as palavras presentes ao longo do livro são fruto também de muitos seres-imagem espirituais, falando através de Kopenawa, que reúne e amplifica esses discursos distintos. $\mathrm{O}$ autor pode tanto acessar as palavras de espíritos dos ancestrais dos brancos, como também dos antigos seres da floresta, dirigindo-as ao leitor não indígena, principalmente, para que possa perceber a complexidade desse mundo. Essa comunicação com o outro não indígena se amplifica também pelo papel de Kopenawa de líder indígena com reconhecimento internacional, mas também por ser o autor do livro. As imagens de palavras inscritas nas páginas de A queda do céu e o nome de Kopenawa na capa os impulsionam para um lugar de autoria e representatividade e auxiliam a ter sua voz ouvida, amplificada e reproduzida.

O discurso yanomami não se concentra apenas na ideia de individualidade e vontade, mas também em relações de localidade e idade: há diversas formas ritualizadas de se conversar na cultura yanomami, como o hereaтии, жауатии, уаітии. Somente pessoas mais velhas e experientes podem falar em hereamии, bem como o discurso yaimuи se limita a espaços rituais, sendo о жауатии о mais abrangente, usado por todos para contar notícias em geral. Kopenawa narra sua vergonha, por exemplo, ao tentar falar em hereamuи, um discurso de pessoas sábias e importantes para os parentes a sua volta, e como o espírito do Gavião Kaokaoma o ajudou nessa tarefa. Assim, por meio desse "eu" utilizado na narrativa, existem diversos discursos assumindo a posição de sujeito, além de outros tantos discursos que são dispostos e contados pelos autores, como palavras vindas de xapiri, dos personagens brancos ao longo da narrativa, de Albert, dos garimpeiros, dos servidores da Funai e dos parentes de Kopenawa, entre outros.

\section{Polifonia da floresta}

Esse processo de multiplicidade de discursos é muito similar à noção bakhtiniana de polifonia e também se conecta ao conceito de perspectivismo ameríndio, o que será melhor desenvolvido a seguir. Viveiros de Castro (2002a) defende que o pensamento ameríndio é 
fundado na ideia de multinaturalismo, em que existe uma inversão da relação entre Natureza e Cultura. Enquanto que, para o Ocidente, existem diversas culturas e modos de pensar de acordo com cada grupo humano, somado a um único mundo compartilhado, para os ameríndios, existe uma única cultura humana, mas que se reflete em uma diversidade de mundos (naturezas) que se realizam de forma diferente para cada ser, ou seja, de acordo com cada perspectiva. Na narrativa de A queda do céu, esse conceito é perceptível, por exemplo, quando Kopenawa afirma que os xapiri veem os humanos como fantasmas, por serem mortais, enquanto os próprios humanos veem os xapiri como fantasmas. Após a queda do primeiro céu, o conjunto de pessoas-animais se transformou nos animais atuais, mas eram antigos seres humanos. No mundo subterrâneo, os seres veem os humanos do mundo de cima como os responsáveis pelos trovões. A humanidade atual mora no topo desse antigo céu desabado, chamado pelos xamãs yanomami de Hutukara, também podendo ser traduzido como natureza/floresta, onde habitam diferentes seres humanos e não humanos.

Essa forma de perceber o mundo de acordo com várias perspectivas distintas, que criam diversos mundos diferentes dependendo do ponto de vista enfocado, é bastante comum no mundo amazônico. Logicamente, há muitas variações dependendo de cada povo, segundo Viveiros de Castro, em que "os humanos são aqueles que continuaram iguais a si mesmos: os animais são ex-humanos, e não os humanos ex-animais" (VIVEIROS DE CASTRO, 2002a, p. 355). Da mesma forma, alguns indivíduos são capazes de, nesse mundo de muitas transformações, serem "interlocutores ativos no diálogo transespecífico" (VIVEIROS DE CASTRO, 2002a, p. 358) - como Kopenawa, capaz de manter contato com diversas entidades espirituais e trazer seus discursos aos humanos, em um processo que envolve política e diplomacia. Assim, diversos seres do mundo (animais, espíritos, divindades, entre outros) possuem uma perspectiva, ou seja, intencionalidade e espírito essencialmente humano, mas veem o mundo de formas diferentes. Isso leva Viveiros de Castro a conceber um multinaturalismo ameríndio, que parte da ideia de que cada ser possui uma forma de ver o mundo, mas essa forma é igualmente baseada na cultura humana. O resultado final é uma diversidade de mundos possíveis face a uma única cultura entre os seres. Nesse processo, o limiar que separa os seres e cria diferentes identidades entre si não é a cultura, e sim seus corpos e como os outros o percebem. Conforme diversas teorias que advogam pela centralidade do corpo para entender as diferenças entre diferentes seres (VILAÇA, 2000; LUCIANI, 2013), são os processos de partilhar as mesmas comidas, viver no mesmo locale 
usar as mesmas roupas, entre outros, que possibilitam que haja identidade entre grupos de pessoas, que passam a assumir corpos semelhantes.

Essa reflexão sobre multinaturalismo, mesmo que bastante resumida, é utilizada aqui instrumentalmente por ser uma ferramenta útil para compreender A queda do céu. Além disso, essa teoria pode também ser conectada, em termos de produção de narrativas, com a ideia bakhtiniana de polifonia. Inicialmente, a obra de Bakhtin, em suas várias vertentes, concentrase em uma busca pelo outro que condensa epistemologicamente as diversas orientações adotadas pelo autor (ARA, 2014, p. 11-12). Bakhtin (2008), ao estudar a obra de Dostoiévski, defende que a obra do autor russo se estrutura em termos do diálogo — que não é um meio, mas um fim (BAKHTIN, 2008, p. 292). Sua análise dos livros de Dostoiévski parte da ideia de que o autor organiza uma série de discursos distintos, mas não assume uma proeminência, permitindo que cada sujeito tenha plenos direitos, não sendo esse mundo narrativo criado apenas por objetos. Cada pensamento é uma posição do homem, cuja intenção principal é mostrar a individualidade do outro, sem haver hierarquias entre autor e personagens. Em relação a isso, Bakhtin afirma que a narrativa do escritor russo permite uma multiplicidade: "Graças a essa variedade de mundos, a matéria pode desenvolver até o fim a sua originalidade e especificidade sem romper a unidade do todo nem mecanizá-la" (BAKHTIN, 2008, p. 16, grifos no original). Nesse contexto, o romance polifônico estudado por Bakhtin centra-se no diálogo e na interação entre diversas consciências, em que o autor não se põe superior a elas, mas combina diversas vontades plenas, em uma obra inteiramente dialógica e, ao mesmo tempo, complexa e permeada por tensão entre essas consciências.

\footnotetext{
Não é a multiplicidade de caracteres e destinos que, em um mundo objetivo uno, à luz da consciência una do autor, se desenvolve nos seus romances; é precisamente a multiplicidade de consciências equipolentes e seus mundos que aqui se combinam numa unidade de acontecimento, mantendo a sua imiscibilidade. Dentro do plano artístico de Dostoiévski, suas personagens são, em realidade, não apenas objetos do discurso do autor, mas os próprios sujeitos desse discurso diretamente significante. (BAKHTIN, 2008, p. 04-05, grifos no original).
}

Neste sentido, salienta-se as diferenças que perpassam as concepções euroamericanas e ameríndias: se, para os ameríndios, há uma mesma cultura em face a uma diversidade de mundos naturais possíveis (e são os corpos e seus pontos de vista que são catalisadores das diferenças), na cosmologia ocidental, há uma unidade da natureza em face a uma diversidade de possíveis culturas (e é o devir histórico e os processos culturais que criam as diferenças entre grupos humanos). Entretanto, também é possível perceber um mesmo arcabouço sobre a 
pluralidade de consciências e vozes que se verifica tanto na teoria bakhtiniana quanto em $A$ queda do céu, mas com realizações diferentes. Em A queda do céu, o "eu" utilizado como ferramenta discursiva congrega diversas consciências e perspectivas distintas tanto de seres humanos quanto não humanos, que compõem uma obra em que diversos discursos, às vezes ambíguos ou contraditórios, são apresentados continuamente. A primeira pessoa presente na narrativa reúne várias outras consciências que são organizadas ao longo do texto, como os xapiri, a presença da redação do antropólogo, os discursos das divindades, a voz dos não indígenas. Cada forma de perceber o mundo é trazida à tona em suas relações ao longo do tempo, partindo do surgimento do mundo e também do primeiro contato com não indígenas.

Já Bakhtin (2008, p. 20) refletindo sobre Dostoiévski, defende que a obra desse autor surge num contexto socioeconômico em que as diversas culturas e comunidades russas passavam por modificações profundas causadas pelo capitalismo, em que não podiam ser mais autossustentáveis e fechadas a novas relações. Nesse caso, é a diferença cultural e histórica que provoca o surgimento de um romance que agrega uma multiplicidade de consciências. Na sociedade yanomami, já havia uma multiplicidade de mundos distintos presentes na relação com os xapiri; porém, a invasão do mundo yanomami, do mesmo modo, foi um encontro disruptivo, que propiciou muitas teorias dos indígenas sobre a origem, poder e paixões dos brancos, e que inicia o "barroquismo turbulento" mencionado por Albert. Nessas relações barrocas, as diferenças são constantemente postas lado a lado, em um mundo que já era permeado por diversos outros espíritos xapiri. Juntamente à dimensão do encontro, ocorre o processo de "virar outro", com as modificações dos autores, tornando-se espíritos, Yanomami, brancos, fantasmas. A queda do céu como narrativa, ela mesma, concentra-se no desejo de Kopenawa de se fazer ouvir para que a floresta não se torne outra, ou seja, que ela morra e que o céu desabe, findando o mundo. Assim, o discurso dos não indígenas é questionado face ao discurso dos xapiri, bem como cada espírito possui suas palavras que são inseridas no contexto da obra através da pessoa de Kopenawa. Desvela-se, desse modo, uma diversidade de mundos, tal qual os diversos mundos da polifonia de Dostoiévski, e tal qual a diversidade de mundos defendida pela teoria do perspectivismo ameríndio.

A noção de polifonia, argumenta-se, pode ser reorganizada, mesmo com suas diferenças contextuais, para refletir sobre a autoria em A queda do céu. Kopenawa descreve a multiplicidade de cantos dos xapiri e sua replicação infinita, como em espelhos voltados um para o outro. Nesse sentido, o papel do xamã é traduzir, sem eliminar ou reduzir, essas diferentes vozes, expondo-as lado a lado em um discurso múltiplo, como as consciências 
equipolentes com seus diversos mundos descritas por Bakhtin (2008). Juntamente a isso, a obra é ocupada também por um antropólogo francês e outras agências, como o sogro de Kopenawa. Como Cesarino (2008) havia refletido, há uma relação de fractalidade no pensamento xamânico e ameríndio, em que um mesmo esquema replica-se em diferentes níveis - como os xapiri que habitam o peito dos xamãs, a Hutukara que abriga a floresta e os xapiri. Esse esquema também pode ser entendido como uma polifonia que se presentifica na obra. Se o pensamento xamânico é múltiplo e ocupado por uma miríade de diferentes seres, dos quais cada voz é traduzida pelo xamã, também podemos pensar em uma polifonia de vozes - não só voltada à consciência individual do autor em um processo histórico turbulento, como no Dostoiévski de Bakhtin, mas também em uma polifonia de diferentes autores que, eles mesmo, são ocupados por devires distintos e variados espíritos, e que são traduzidos e dispostos na obra.

Sendo assim, a autoria em $A$ queda do céu modifica as relações inicialmente apresentadas no texto, concentradas no individualismo, que é eclipsado por uma polifonia de vozes e discursos que se reúnem na figura do "eu" narrador e nos diversos outros discursos, atores e agências elencados na narrativa. Como Foster (2014) já estudava ao escrever sobre o "retorno do autor", esse retorno acontece como uma forma de continuar seu questionamento, em uma intenção de artistas de procurar novos discursos e falar sobre a alteridade. Já em $A$ queda do céu, a autoria aparece como um discurso ele mesmo complexo, na forma de diversos autores e vozes polifônicas, em que a própria autoria, como uma individualidade ligada a processos capitalistas, perde relevância frente às vozes da floresta e ao contínuo tornar-se outro.

\section{Conclusão}

Há uma imagem em "O Nativo Relativo" (VIVEIROS DE CASTRO, 2002b) sobre como certos grupos indígenas consideram humanos os pecaris. Essa afirmação, diz o autor, não nos ajuda a entender os pecaris, mas sim os grupos indígenas que o afirmam. Também neste trabalho isso ocorre: podemos compreender, a partir das transformações por que Kopenawa e Albert passam em seus encontros e em seus discursos, uma pluralidade de vozes que alargam o conceito de autoria e discurso comumente compreendido nas obras literárias. Se, como argumenta Nodari $(2015$, p. 81$)$, a antropologia funciona como uma cartografia de 
mundos possíveis e a literatura como uma cartografia dos mundos inexistentes, podemos encontrar aqui uma situação intermediária. A transformação de Kopenawa ao longo de sua trajetória, com encontros com estrangeiros, desejos de virar branco, reconstruções corporais feitas por xapiri e lutas políticas, e as transformações que Albert tem em seus encontros e aproximações com o Yanomami, tudo isso se materializa em um discurso sem um gênero claro - mas que revela a intensa variação dos sujeitos e, por conseguinte, de cada voz que é alinhavada na obra.

Se podemos pensar nas noções de autoria ocidentais, centradas no sujeito e em suas transformações pessoais e culturais, formando uma polifonia de sujeitos sociais, podemos aqui ampliar essa noção para uma polifonia de agentes do cosmos, isto é, alteridades presentes nos próprios autores que os transformam e se fazem presentes em suas narrativas. A polifonia, nesse caso, não é somente entre as consciências humanas que dialogam entre si, como Bakhtin analisou a partir da obra de Dostoiévski, mas também uma polifonia de sujeitos da floresta, de estrangeiros e espíritos que se intercalam e constroem um gênero ensaístico, autorreflexivo, autoantropológico, mas cuja dificuldade de enquadrar em categorias textuais ocidentais é resultado da polifonia que criou a obra.

A queda do се́u se constitui através de múltiplos gêneros (SALLES, 2017; 2021), variando entre autobiografia, tratado xamânico, antropologia reversa, anti-antropologia, relato de vida, relato de viagens, relato onírico e manifesto cosmopolítico. Nesse quesito, não há apenas multiplicidade nos gêneros encontrados no livro, mas também em sua escrita, contendo tanto a alfabética quanto a pictoglífica (DORRICO, 2018), as narrativas e palavras de Davi Kopenawa vêm acompanhadas de seus desenhos dos xapiri, da floresta e dos brancos, o que transparece inclusive no processo de criação e autoria deste livro.

Por fim, lembramos que Krenak (2019) conclama-nos a refletir e entender a multiplicidade de nossas humanidades com o objetivo de criar uma cartografia de um mundo prestes a inexistir. Não é por acaso que seja esse o mesmo objetivo explícito de Kopenawa presente na imagem (ou premonição) da queda do céu, o futuro em que o mundo se destrói. Ao entender, levar a sério, compreender e estudar esses mundos possíveis - e suas multiplicidades de vozes e humanidades - podemos entender e alargar a noção de autoria e discurso na própria obra, mas, especialmente, entender uma pluralidade de vozes que podem ser ouvidas além de uma noção centrada no sujeito ocidental. 


\section{REFERÊNCIAS}

ALBERT, Bruce. O ouro canibal e a queda do céu: uma crítica xamânica da economia política da natureza (Yanomami). In: ALBERT, Bruce; RAMOS, Alcida Rita (Org.). Pacificando o branco: cosmologias do contato norte-amazônico. São Paulo: UNESP, 2002. p. 239-276.

ARA, Pampa Olga. A questão do autor em Bakhtin. Bakhtiniana - Revista de Estudos do Discurso, São Paulo, v. 9, p. 4-25, 2014.

BAKHTIN, Mikhail. Problemas da poética de Dostoiévski. Rio de Janeiro: Forense Universitária, 2008.

BARTHES, Roland. A morte do autor. In: BARTHES, Roland. O rumor da língua. São Paulo: Martins Fontes, 2004. p. 57-64.

BHABHA, Homi K. O local da cultura. Belo Horizonte: Editora da UFMG, 1998.

CALAVIA SÁEZ, Oscar. A ética da pesquisa na era da autoria: direito intelectual indígena, socialidade e invenção antropológica. Revista brasileira de Ciências Sociais, São Paulo, v. 28, n. 83, p. 73-84, out. 2013.

CESARINO, Pedro. A divergência original: tradução xamanística e tradução etnográfica. In: REUNIÃO BRASILEIRA DE ANTROPOLOGIA, XXVI, 2008, Porto Seguro. Anais [...]. Porto Seguro: ABA, 2008, p. 1-21.

DANNER, Leno Francisco; DORRICO, Julie. A literatura indígena como crítica da modernidade: sobre xamanismo, normatividade e universalismo - notas desde A queda do céu: palavras de um xamã yanomami, de Davi Kopenawa e Bruce Albert. O Eixo e a Roda: Revista de Literatura Brasileira, Belo Horizonte, v. 26, n. 3, p. 129-156, 2017.

DORRICO, Julie. A literatura indígena contemporânea brasileira: a oralidade no impresso na obra A queda do céu: palavras de um xamã yanomami de Davi Kopenawa e Bruce Albert. Revista Língua\&Literatura, Frederico Westphalen, v. 20, n. 36, p. 132-150, 2018.

FOSTER, Hal. O retorno do real. São Paulo: Cosac Naify, 2014

FOUCAULT, Michel. O que é um autor? In: FOUCAULT, Michel. Ditos e escritos: estética - literatura e pintura, música e cinema. v. III. Rio de Janeiro: Forense Universitária, 2001. p. 264-298.

KLINGER, Diana. Escritas de si, escritas do outro: O retorno do autor e a virada etnográfica. Rio de Janeiro: 7Letras, 2007.

KOPENAWA, Davi; ALBERT, Bruce. Descobrindo os brancos. In: NOVAES, Adauto (Org.). A Outra margem do Ocidente. São Paulo: Companhia das Letras, 1999. p. 15-21.

KOPENAWA, Davi; ALBERT, Bruce. A queda do céu: palavras de um xamã yanomami. São Paulo: Cia. das Letras, 2015. 
KRENAK, Ailton. Ideias para adiar o fim do mundo. São Paulo: Companhia das Letras, 2019.

LUCIANI, José Antonio Kelly. La chute du ciel. Paroles d'un chaman yanomami. $R @ U$ Revista de Antropologia da UFSCar, São Carlos, v. 5, n. 1, p. 172-187, jan.-jun. 2013.

NODARI, Alexandre Andre. A literatura como antropologia especulativa. Revista da ANPOLL, Brasília, v. 1, n. 38, p. 75-85, 2015.

SALLES, Juliana. A. Eu, tu e nós: questões identitárias e literárias em A queda do céu: palavras de um xamã yanomami. In: CONGRESSO INTERNACIONAL DA ABRALIC, XV, 017, Rio de Janeiro. Anais [...]. Rio de Janeiro: ABRALIC, 2017, p. 6430-6441.

SALLES, Juliana. A. O relato de vida indígena e outros (sub)gêneros literários em A queda do céu: palavras de um xamã yanomami, Meu nome é Rigoberta Menchu e assim nasceu minha consciência e Bobbi Lee: Indian Rebel struggles of a Native Canadian woman. Ilha do Desterro, Florianópolis, v. 74, p. 231-250, 2021.

SANTOS-GRANERO, Fernando. Introduction: Amerindian Constructional Views of the World. In: SANTOS-GRANERO, Fernando (Ed.). The Occult Life of Things: Native Amazonian Theories of Materiality and Personhood. The University of Arizona Press, 2009. p. 1-29.

VILAÇA, Aparecida. O que significa tornar-se outro? Xamanismo e contato interétnico na Amazônia. Revista Brasileira de Ciências Sociais, São Paulo, v. 15, p. 56-72, 2000.

VIVEIROS DE CASTRO, Eduardo. Perspectivismo e multinaturalismo na América Indígena. In: VIVEIROS DE CASTRO, Eduardo. A inconstância da alma selvagem e outros ensaios de antropologia. São Paulo: Cosac Naify, 2002a. p. 345-400.

VIVEIROS DE CASTRO, Eduardo. O nativo relativo. Mana, Rio de Janeiro, v. 8, p. 113$148,2002 b$.

VIVEIROS DE CASTRO, Eduardo. A floresta de cristal: notas sobre a ontologia dos espíritos amazônicos. Cadernos de Campo (São Paulo 1991), São Paulo, v. 15, n. 14-15, p. 319-338, 2006.

VIVEIROS DE CASTRO, Eduardo. Prefácio: o recado da mata. In: KOPENAWA, Davi; ALBERT, Bruce. A queda do céu: palavras de um xamã yanomami. São Paulo: Companhia das Letras, 2015. p. 11-41.

VIVEIROS DE CASTRO, Eduardo; SZTUTMAN, Renato; NASCIMENTO, Silvana; MARRAS, Stellio. O chocalho do xamã é um acelerador de partículas: entrevista com Eduardo Viveiros de Castro. In: SZTUTMAN, Renato. Encontros com Eduardo Viveiros de Castro. Rio de Janeiro: Beco do Azougue, 2008, p. 26-49.

Artigo submetido em: 08 jul. 2021

Aceito para publicação em: 10 out. 2021

DOI: https://dx.doi.org/10.22456/2238-8915.116634 